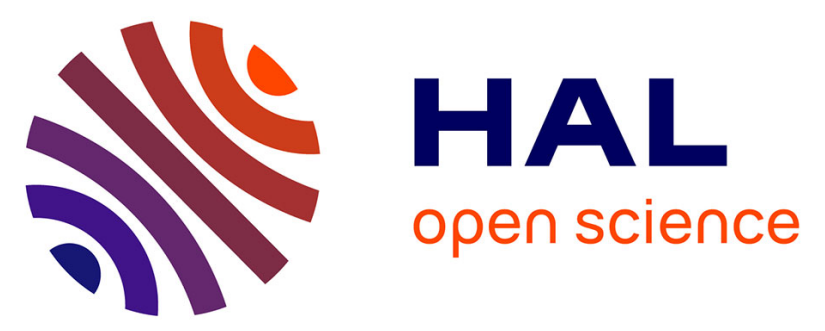

\title{
Clearance of vancomycin during continuous infusion in Intensive Care Unit patients: correlation with measured and estimated creatinine clearance and serum cystatin $\mathrm{C}$
}

Martin G. Kees, Justus W. Hilpert, Carsten Gnewuch, Frieder Kees, Stephan Voegeler

\section{To cite this version:}

Martin G. Kees, Justus W. Hilpert, Carsten Gnewuch, Frieder Kees, Stephan Voegeler. Clearance of vancomycin during continuous infusion in Intensive Care Unit patients: correlation with measured and estimated creatinine clearance and serum cystatin C. International Journal of Antimicrobial Agents, 2010, 36 (6), pp.545. 10.1016/j.ijantimicag.2010.07.015 . hal-00640450

\section{HAL Id: hal-00640450 \\ https://hal.science/hal-00640450}

Submitted on 12 Nov 2011

HAL is a multi-disciplinary open access archive for the deposit and dissemination of scientific research documents, whether they are published or not. The documents may come from teaching and research institutions in France or abroad, or from public or private research centers.
L'archive ouverte pluridisciplinaire HAL, est destinée au dépôt et à la diffusion de documents scientifiques de niveau recherche, publiés ou non, émanant des établissements d'enseignement et de recherche français ou étrangers, des laboratoires publics ou privés. 


\section{Accepted Manuscript}

Title: Clearance of vancomycin during continuous infusion in Intensive Care Unit patients: correlation with measured and estimated creatinine clearance and serum cystatin C

Authors: Martin G. Kees, Justus W. Hilpert, Carsten

Gnewuch, Frieder Kees, Stephan Voegeler

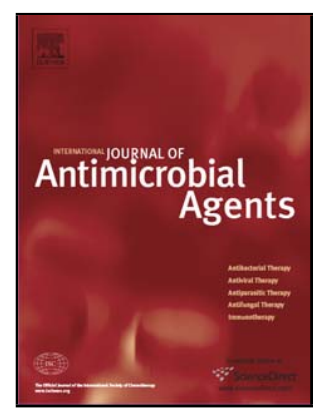

PII: S0924-8579(10)00343-2

DOI:

Reference: doi:10.1016/j.ijantimicag.2010.07.015

To appear in: International Journal of Antimicrobial Agents

Received date: $\quad 16-5-2010$

Revised date: $\quad 21-7-2010$

Accepted date: $\quad$ 24-7-2010

Please cite this article as: Kees MG, Hilpert JW, Gnewuch C, Kees F, Voegeler S, Clearance of vancomycin during continuous infusion in Intensive Care Unit patients: correlation with measured and estimated creatinine clearance and serum cystatin C, International Journal of Antimicrobial Agents (2010), doi:10.1016/j.ijantimicag.2010.07.015

This is a PDF file of an unedited manuscript that has been accepted for publication. As a service to our customers we are providing this early version of the manuscript. The manuscript will undergo copyediting, typesetting, and review of the resulting proof before it is published in its final form. Please note that during the production process errors may be discovered which could affect the content, and all legal disclaimers that apply to the journal pertain. 
Clearance of vancomycin during continuous infusion in Intensive

Care Unit patients: correlation with measured and estimated creatinine clearance and serum cystatin $\mathbf{C}$

Martin G. Kees ${ }^{a, *}$, Justus W. Hilpert ${ }^{a}$, Carsten Gnewuch ${ }^{b}$, Frieder Kees ${ }^{c}$, Stephan Voegeler $^{\mathrm{a}}$

${ }^{a}$ Department of Anesthesiology and Intensive Care, Charité University Hospital

Berlin, Campus Benjamin Franklin, Hindenburgdamm 30, 12200 Berlin, Germany

${ }^{\mathrm{b}}$ Institute for Clinical Chemistry and Laboratory Medicine, University of Regensburg,

Universitätsstr. 31, 93053 Regensburg, Germany

${ }^{c}$ Department of Pharmacology, University of Regensburg, Universitätsstr. 31, 93053

Regensburg, Germany

ARTICLE INFO

Article history:

Received 16 May 2010

Accepted 24 July 2010

Keywords:

HPLC

Pharmacokinetics

ICU

Cystatin C

Creatinine clearance 
Dosing

* Corresponding author. Tel.: +49 308445 2731; fax: +49 3084454469.

E-mail address: martin.kees@charite.de (M.G. Kees). 


\section{ABSTRACT}

Vancomycin (VAN) dosing requires adjustment to renal function, which is often estimated using the Cockcroft-Gault formula; however, its precision is poor in Intensive Care Unit (ICU) patients. VAN clearance ( $\left.\mathrm{CL}_{\text {van }}\right)$ during continuous infusion was prospectively determined in $25 \mathrm{ICU}$ patients [14 male, 11 female; age range 3182 years; body mass index (BMI) $16.5-41.5 \mathrm{~kg} / \mathrm{m}^{2}$; Acute Physiology and Chronic Health Evaluation (APACHE) II score at admission 8-36; creatinine clearance 25$195 \mathrm{~mL} / \mathrm{min})$ and its correlation with measured creatinine clearance $\left(\mathrm{CL}_{\mathrm{Crea}}\right)$, estimated creatinine clearance using the Cockcroft-Gault formula $\left(\mathrm{CL}_{\mathrm{CG}}\right)$ and estimated glomerular filtration rate according to Hoek's formula based on serum

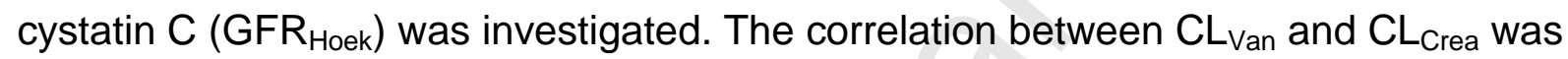
very good $\left(r^{2}=0.88\right)$, but it was rather poor with $\mathrm{CL}_{\mathrm{CG}}\left(r^{2}=0.37\right)$ and was acceptable with $\operatorname{GFR}_{\text {Hoek }}\left(r^{2}=0.70\right)$. For VAN dose adjustments in ICU patients, determination of cystatin $\mathrm{C}$ may be an interesting and practical alternative to measured $\mathrm{CL}_{\mathrm{Crea}}$, whereas the Cockcroft-Gault formula should be used with caution. 


\section{Introduction}

Vancomycin (VAN) is still the standard treatment for infections caused by meticillinresistant Staphylococcus aureus (MRSA), despite the introduction of some alternative agents $[1,2]$. However, the narrow therapeutic range and a trend towards higher minimum inhibitory concentrations (MICs) make precise dosing of VAN preferable for successful treatment and, for this purpose, sound population-specific pharmacokinetic data are required [3].

VAN is predominantly eliminated via the kidney and the maintenance dose is mainly determined by the glomerular filtration rate (GFR) [4]. The GFR can be determined by various methods, the validity of which are typically proportional to effort. Whereas clearance of exogenous substances such as inulin is the suggested gold standard, measured creatinine clearance can be considered as the clinical reference standard. Assuming constant and predictable production of creatinine, its clearance can be estimated from serum creatinine alone, e.g. using the popular Cockcroft-Gault formula [5]. By analogy, serum cystatin C has been established as an indicator of GFR [6].

Surprisingly, there are only few pharmacokinetic studies on VAN in Intensive Care Unit (ICU) patients without renal replacement therapy. Only one study used a classic prospective pharmacokinetic design [7], whereas three other studies retrospectively analysed data from routine therapeutic drug monitoring (TDM) [8-10]. These studies exclusively used estimations based on serum creatinine as a measure of renal function, although the underlying assumptions are particularly questionable in critically ill patients [11-16]. Consequently, in these studies a large part of the 
variance in VAN clearance remains unaccounted for. It is unclear whether this reflects unknown physiological changes during critical illness or the shortcomings of the applied methods.

Although clinical superiority in terms of outcome has not been demonstrated, there is substantial theoretical support for continuous infusion of VAN [17]. In the surgical ICU at Charité University Hospital, Campus Benjamin Franklin (Berlin, Germany), continuous infusion is applied as the standard administration form because it simplifies interpretation of TDM and dose adjustments. As an ancillary effect, continuous infusion permits easy determination of drug clearance. At steady state, determination of a single plasma concentration would suffice for calculation of clearance.

The aim of this study was to determine VAN clearance $\left(\mathrm{CLVan}_{\text {Van }}\right)$ in ICU patients during continuous infusion and to investigate its relationships with measured creatinine clearance $\left(\mathrm{CL}_{\mathrm{Crea}}\right)$, estimated creatinine clearance using the Cockcroft-Gault formula ( $\mathrm{CL}_{\mathrm{CG}}$ ) and estimated GFR according to Hoek's formula based on serum cystatin C (GFR $\left.\mathrm{R}_{\text {Hoek }}\right)$, as a basis for dosing recommendations.

\section{Patients and methods}

\subsection{Study design and patients}

This prospective, single-centre study was approved by the Institutional Ethics Committee of Charité University Hospital. Adult patients in the 22-bed surgical ICU who received treatment with VAN continuous infusion were enrolled. Patients 
undergoing renal replacement therapy were excluded. Written informed consent was obtained from either the patient or their legal representative.

\subsection{Vancomycin dosage and therapeutic drug monitoring}

The attending physician started VAN treatment when infection by a susceptible pathogen was proven or suspected. According to the internal protocol, a loading dose was administered as a 1-h infusion, followed by continuous infusion of VAN. The initial infusion rate was chosen according to the estimated creatinine clearance. Daily at 05:00h, TDM was performed and the infusion rate was adjusted to a target concentration between $20 \mathrm{mg} / \mathrm{L}$ and $25 \mathrm{mg} / \mathrm{L}$.

\subsection{Pharmacokinetic calculations}

As soon as routine TDM showed the VAN serum concentration to be within the desired range and the infusion rate had not been changed for more than $24 \mathrm{~h}$, blood was sampled from arterial catheters at 11:00h, 17:00h, 23:00h and 05:00h. Urine was collected quantitatively in three 6-h fractions from 11:00h to 05:00h. VAN and creatinine concentrations were determined in all serum specimens and, owing to budgetary restrictions, cystatin $\mathrm{C}$ was determined only in the first and last specimens. Urine specimens were analysed for creatinine.

Clearance of VAN ( $\left.\mathrm{CL}_{\text {van }}\right)$ and creatinine clearance $\left(\mathrm{CL}_{\mathrm{Crea}}\right)$ were calculated as follows:

$\mathrm{CL}_{\mathrm{Van}}=$ infusion rate of VAN/serum concentration of VAN 
$\mathrm{CL}_{\text {Crea }}=($ urine volume $\times$ urine concentration of creatinine $) /($ collection time $\times$ serum concentration of creatinine)

Creatinine clearance based on serum creatinine $\left(\mathrm{CL}_{\mathrm{CG}}\right)$ was estimated using the Cockcroft-Gault formula [5]:

$\mathrm{CL}_{\mathrm{CG}}(\mathrm{mL} / \mathrm{min})=[140-$ age $($ years $)] \times$ weight $(\mathrm{kg}) /[72 \times$ serum creatinine $(\mathrm{mg} / \mathrm{dL})] \times$ 0.85 for women

GFR based on serum cystatin C was estimated by the Hoek formula (GFR $\mathrm{Hoek}_{\text {) }}$ [18] and the Du Bois formula for body surface area (BSA) [19]:

GFR $_{\text {Hoek }}=[80.35 /$ serum cystatin $\mathrm{C}(\mathrm{mg} / \mathrm{L})-4.32] \mathrm{mL} / \mathrm{min} / 1.73 \mathrm{~m}^{2} \times \mathrm{BSA}$

BSA $\left(\mathrm{m}^{2}\right)=0.007184 \times$ height $(\mathrm{cm})^{0.725} \times$ weight $(\mathrm{kg})^{0.425}$

\subsection{Analysis of vancomycin, creatinine and cystatin $C$}

Blood samples were allowed to clot for $30 \mathrm{~min}$, centrifuged and stored at $-20^{\circ} \mathrm{C}$. Urine samples were frozen at $-20^{\circ} \mathrm{C}$ without prior treatment. Routine TDM was performed in the hospital's central laboratory (Patients 1 to 13, VANC2, Roche Diagnostics, Mannheim, Germany; and Patients 14 to $25, \mathrm{QMS}^{\circledR}$ Vancomycin, Thermo Fisher Scientific, Dreieich, Germany). Serum concentrations of VAN for pharmacokinetic calculations were assayed by high-performance liquid 
chromatography (HPLC) with photometric detection at $240 \mathrm{~nm}$ as previously described [20]. A reversed-phase column (Gemini-NX C18, $3 \mu \mathrm{m}$, internal diameter $15 \times 0.46 \mathrm{~cm}$; Phenomenex, Aschaffenburg, Germany) was used for separation with an eluent composed of $1000 \mathrm{~mL}$ of $50 \mathrm{mM}$ sodium dihydrogen phosphate and 100 $\mathrm{mL}$ of acetonitrile. The $\mathrm{pH}$ was adjusted to 3.9 with o-phosphoric acid. Interference by concomitant medication in a few patients could be avoided by adjusting the $\mathrm{pH}$ between 3.9 and 3.1 , as the retention time of VAN is sensitive to $\mathrm{pH}$. Based on spiked quality control samples, intra- and inter-assay imprecision as well as bias were $<5 \%$.

Concentrations of creatinine were determined enzymatically using an ADVIA Chemistry System (ECRE 2; Siemens Healthcare Diagnostics, Eschborn, Germany). Concentrations of cystatin $\mathrm{C}$ were determined using a $\mathrm{BN}^{\mathrm{TM}}$ II Nephelometer (Siemens Healthcare Diagnostics).

\subsection{Statistical analysis}

SPSS 17 for Mac OS X (SPSS Inc., Chicago, IL) was used for statistical analysis.

Parametric linear regression was used to evaluate correlations between parameters. Two-sided $\alpha$ errors $<0.05$ were considered statistically significant and were reported as $P$-values. Data are presented as median (range) or mean (95\% confidence interval), as appropriate. 


\section{Results}

A total of 25 patients (14 male, 11 female) were enrolled in the study (Table 1). Most commonly, sampling was performed around Day 5 (range, Day 2-15) of treatment with VAN. In one patient, only one 6-h interval (two serum samples and one urine fraction) was available because VAN treatment was terminated. The concentrations were sufficiently constant to assume steady-state conditions in 24 patients, whereas in 1 patient a continuous decline of $32 \%$ over $18 \mathrm{~h}$ was observed, probably due to acute arterial hypertension with enhanced glomerular filtration. In this patient, only the last concentration, which is closest to steady-state, was used to calculate $\mathrm{CL}_{\text {van }}$.

The study population exhibited a wide range of renal function, with a median $\mathrm{CL}_{\text {Crea }}$ of $106 \mathrm{~mL} / \mathrm{min}$ (range $25-195 \mathrm{~mL} / \mathrm{min}$ ), providing an excellent basis to assess the relationship between $\mathrm{CL}_{\mathrm{van}}$ and renal function. Fig. 1 depicts the relationships between $\mathrm{CL}_{\mathrm{Van}}$ with $\mathrm{CL}_{\mathrm{Crea}}, \mathrm{CL}_{\mathrm{CG}}$ and $\mathrm{GFR}_{\mathrm{H} \text { Hok. }}$. The respective regression equations and coefficients of determination are shown in Table 2.

\section{Discussion}

The present study compares measured creatinine clearance $\left(C L_{C r e a}\right)$, creatinine clearance estimated by the Cockcroft-Gault formula from serum creatinine $\left(\mathrm{CL}_{\mathrm{CG}}\right)$ and GFR estimated by the Hoek formula from serum cystatin C (GFR Hoek $_{\text {) as }}$ determinants of $\mathrm{CL}_{\operatorname{Van}}$ in ICU patients.

As could be expected, $\mathrm{CL}_{\mathrm{Crea}}$ showed the closest correlation with $\mathrm{CL}_{\mathrm{van}}$ with a residual error $\left(1-r^{2}\right)$ of only ca. $12 \%$, which includes measurement errors and further 
undetected covariates. Apart from analytical errors, pharmacokinetic calculations assume constant physiological conditions throughout the study period, which is probably never true in ICU patients. Thus, it seems unlikely that further research would identify additional relevant covariates of $\mathrm{CL}_{\mathrm{van}}$ in comparable populations.

In principle, estimation of GFR based on serum concentrations of endogenous markers alone works like the calculation of drug clearance during continuous infusion, as applied in this study for VAN:

Clearance $=$ infusion or production rate/serum concentration

For ideal markers, which undergo exclusive elimination by free glomerular filtration, clearance would be equal to the GFR, whilst restricted filtration, secretion, reabsorption or non-renal clearance may require corrective factors. The CockcroftGault formula estimates creatinine production from age, weight and sex, whereas the Hoek formula assumes cystatin $\mathrm{C}$ production to be proportional to BSA. Catabolism, immobilisation and other disturbances of homeostasis negatively affect the precision of these formulas in ICU patients, as has been documented by a number of previous studies [11-16].

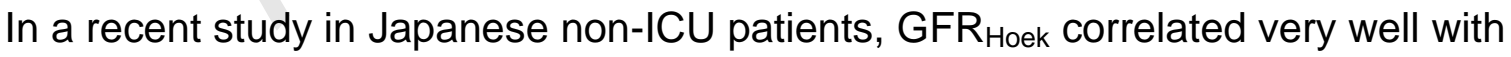
$\mathrm{CL}_{\operatorname{Van}}\left(r^{2}=0.84\right)$ [21]. As outlined above, it is not surprising that the formula performs worse in the ICU patients in the current study, but the correlation $\left(r^{2}=0.70\right)$ seems acceptable. We would like to emphasise that the Hoek formula estimates GFR, which 
is systematically lower than creatinine clearance owing to some tubular secretion of creatinine.

Regarding $\mathrm{CL}_{\mathrm{CG}}$, although the correlation is statistically highly significant, its value in predicting $\mathrm{CL}_{\text {van }}$ in ICU patients seems doubtful. Other studies in ICU patients reported correlations with $r^{2}$ between 0.43 and 0.56 [7-10], which is somewhat better than in the data here $\left(r^{2}=0.37\right)$. However, in one study patients who had been in hospital for more than 14 days were excluded [8], and in another study the Cockcroft-Gault formula was modified by truncating values above $120 \mathrm{~mL} / \mathrm{min}$ [10]. It should be kept in mind that exact values throughout all the pathophysiological range are required for reliable drug dosing, not just the discrimination of normal from abnormal renal function.

Of course, using the Cockcroft-Gault formula is probably the easiest and least expensive way to obtain an estimate of renal function. However, collecting urine in ICU patients is typically performed anyway for calculating fluid balances and seems a small additional effort, which is rewarded by a substantial gain in precision. Several studies suggest that short collection periods of $1-2 \mathrm{~h}$ are sufficient for accurate measurements $[11,12,22,23]$. We therefore recommend the use of measured $\mathrm{CL}_{\mathrm{Crea}}$ for prediction of CLVan in ICU patients.

Our data can be used as a basis to predict dosing requirements. Current recommendations suggest an area under the concentration-time curve from 0-24 $\mathrm{h}$ $\left(\mathrm{AUC}_{24 \mathrm{~h}}\right) / \mathrm{MIC}$ of $400 \mathrm{~h}$ as the relevant pharmacokinetic/pharmacodynamic target [3], which corresponds to a mean serum concentration ( $\left.C_{\text {mean }}\right)$ of $16.7 \mathrm{mg} / \mathrm{L}$ for an MIC of 
$1.0 \mathrm{mg} / \mathrm{L}$. For continuous infusion, target concentrations between $15 \mathrm{mg} / \mathrm{L}$ and 25 $\mathrm{mg} / \mathrm{L}$ (free concentrations of $4-5 \times \mathrm{MIC}$ ) have been suggested $[8,24,25]$. The daily maintenance dose $(\mathrm{dMD})$ can be calculated as $\mathrm{dMD}=1440 \mathrm{~min} \times C_{\text {mean }} \times(0.63 \times$ $\left.\mathrm{CL}_{\text {Crea }}+2.8 \mathrm{~mL} / \mathrm{min}\right)$, or $\mathrm{dMD}=\mathrm{AUC}_{24 \mathrm{~h}} \times\left(0.63 \times \mathrm{CL}_{\text {Crea }}+2.8 \mathrm{~mL} / \mathrm{min}\right)$. Owing to the linear pharmacokinetics of VAN [26], $\mathrm{AUC}_{24 \mathrm{~h}}$ is independent of the dosing regimen (i.e. it is the same whether the daily dose is given as one, two, four or an infinite number of single doses). Therefore, according to classic pharmacokinetic theory the formula should also be applicable to intermittent infusion. Using the Hoek formula, the expression $\left(0.63 \times \mathrm{CL}_{\text {Crea }}+2.8 \mathrm{~mL} / \mathrm{min}\right)$ needs to be replaced by $\left(0.67 \times \mathrm{GFR}_{\text {Hoek }}\right.$ $+3.2 \mathrm{~mL} / \mathrm{min}$ ). We advise against the use of the Cockcroft-Gault formula for calculating dosing requirements.

Finally, some limitations of this study must be mentioned. This study was performed on a surgical ICU in a university hospital. The majority of patients underwent neurosurgery or general surgery. The results should be extrapolated with caution to other populations.

Calculation of $\mathrm{CL}_{\text {van }}$ in this study requires the presence of steady state. Long halflives make it difficult to attain the real equilibrium, and even impossible if clinical conditions change as is likely in ICU patients. As the individual concentration-time courses were fairly constant and the number of patients with rising or falling concentrations was well balanced, we consider this error small and not systematic. 
The dosing recommendations are derived from descriptive data only. Their predictive performance should be validated in prospective studies with heterogeneous populations.

To summarise, we demonstrated in ICU patients that $\mathrm{CL}_{V a n}$ is closely correlated with measured $\mathrm{CL}_{\mathrm{Crea}}$, which is therefore a good basis for estimating dosing requirements. Serum cystatin $\mathrm{C}$ may be a useful and practical alternative. Use of the CockcroftGault formula bears large uncertainties in this context.

\section{Acknowledgments}

The authors thank the medical and nursing staff on the surgical ICU at Charité University Hospital, Campus Benjamin Franklin (Berlin, Germany) for their reliable help as well as Dr Karin Hensel-Wiegel, Department of Clinical Chemistry, for her cooperation.

\section{Funding}

This work was supported by institutional sources only.

\section{Competing interests}

None declared.

\section{Ethical approval}

Ethical approval was received from the Institutional Ethics Committee of the Charité University Hospital, Campus Benjamin Franklin (reference no. EA4/113/07). 


\section{References}

[1] American Thoracic Society; Infectious Diseases Society of America. Guidelines for the management of adults with hospital-acquired, ventilator-associated, and healthcare-associated pneumonia. Am J Respir Crit Care Med 2005;171:388416.

[2] Tunkel AR, Hartman BJ, Kaplan SL, Kaufman BA, Roos KL, Scheld WM, et al. Practice guidelines for the management of bacterial meningitis. Clin Infect Dis 2004;39:1267-84.

[3] Rybak M, Lomaestro B, Rotschafer JC, Moellering R, Craig W, Billeter M, et al. Therapeutic monitoring of vancomycin in adult patients: a consensus review of the American Society of Health-System Pharmacists, the Infectious Diseases Society of America, and the Society of Infectious Diseases Pharmacists. Am J Health Syst Pharm 2009;66:82-98.

[4] Moellering RC. Pharmacokinetics of vancomycin. J Antimicrob Chemother 1984;14(Suppl D):43-52.

[5] Cockcroft DW, Gault MH. Prediction of creatinine clearance from serum creatinine. Nephron 1976;16:31-41.

[6] Dharnidharka VR, Kwon C, Stevens G. Serum cystatin C is superior to serum creatinine as a marker of kidney function: a meta-analysis. Am J Kidney Dis 2002;40:221-6.

[7] Polard E, Le Bouquin V, Le Corre P, Kérebel C, Trout H, Feuillu A, et al. Non steady state and steady state PKS Bayesian forecasting and vancomycin pharmacokinetics in ICU adult patients. Ther Drug Monit 1999;21:395-403.

[8] Pea F, Furlanut M, Negri C, Pavan F, Crapis M, Cristini F, et al. Prospectively validated dosing nomograms for maximizing the pharmacodynamics of 
vancomycin administered by continuous infusion in critically ill patients.

Antimicrob Agents Chemother 2009;53:1863-7.

[9] Del Mar Fernández de Gatta Garcia M, Revilla N, Calvo MV, Domínguez-Gil A, Sánchez Navarro A. Pharmacokinetic/pharmacodynamic analysis of vancomycin in ICU patients. Intensive Care Med 2007;33:279-85.

[10] Llopis-Salvia P, Jiménez-Torres NV. Population pharmacokinetic parameters of vancomycin in critically ill patients. J Clin Pharm Ther 2006;31:447-54.

[11] Hoste EAJ, Damen J, Vanholder RC, Lameire NH, Delanghe JR, Van den Hauwe $\mathrm{K}$, et al. Assessment of renal function in recently admitted critically ill patients with normal serum creatinine. Nephrol Dial Transplant 2005;20:747-53.

[12] Herrera-Gutiérrez M, Seller-Pérez G, Banderas-Bravo E, Muñoz-Bono J, Lebrón-Gallardo M, Fernandez-Ortega J. Replacement of 24-h creatinine clearance by $2-h$ creatinine clearance in intensive care unit patients: a singlecenter study. Intensive Care Med 2007;33:1900-6.

[13] Conil JM, Georges B, Fourcade O, Seguin T, Lavit M, Samii K, et al. Assessment of renal function in clinical practice at the bedside of burn patients. $\mathrm{Br}$ J Clin Pharmacol 2007;63:583-94.

[14] Cherry RA, Eachempati SR, Hydo L, Barie PS. Accuracy of short-duration creatinine clearance determinations in predicting 24-hour creatinine clearance in critically ill and injured patients. J Trauma 2002;53:267-71.

[15] Martin JH, Fay MF, Udy A, Roberts J, Kirkpatrick C, Ungerer J, et al. Pitfalls of using estimations of glomerular filtration rate in an intensive care population. Intern Med J 2010 Jan 4 [Epub ahead of print]. doi: 10.1111/j.1445$5994.2010 .02160 . x$ 
[16] Poggio ED, Nef PC, Wang X, Greene T, Van Lente F, Dennis VW, et al. Performance of the Cockcroft-Gault and Modification of Diet in Renal Disease equations in estimating GFR in ill hospitalized patients. Am J Kidney Dis 2005;46:242-52.

[17] Roberts JA, Lipman J, Blot S, Rello J. Better outcomes through continuous infusion of time-dependent antibiotics to critically ill patients? Curr Opin Crit Care $2008 ; 14: 390-6$.

[18] Hoek FJ, Kemperman FAW, Krediet RT. A comparison between cystatin C, plasma creatinine and the Cockcroft and Gault formula for the estimation of glomerular filtration rate. Nephrol Dial Transplant 2003;18:2024-31.

[19] Du Bois D, Du Bois EF. A formula to estimate the approximate surface area if height and weight be known. Arch Intern Med 1916;17:863-71.

[20] Beckmann J, Kees F, Schaumburger J, Kalteis T, Lehn N, Grifka J, et al. Tissue concentrations of vancomycin and moxifloxacin in periprosthetic infection in rats. Acta Orthop 2007;78:766-73.

[21] Tanaka A, Aiba T, Otsuka T, Suemaru K, Nishimiya T, Inoue T, et al. Population pharmacokinetic analysis of vancomycin using serum cystatin $\mathrm{C}$ as a marker of renal function. Antimicrob Agents Chemother 2010;54:778-82.

[22] Sladen RN, Endo E, Harrison T. Two-hour versus 22-hour creatinine clearance in critically ill patients. Anesthesiology 1987;67:1013-6.

[23] Wilson RF, Soullier G. The validity of two-hour creatinine clearance studies in critically ill patients. Crit Care Med 1980;8:281-4.

[24] Vuagnat A, Stern R, Lotthe A, Schuhmacher H, Duong M, Hoffmeyer P, et al. High dose vancomycin for osteomyelitis: continuous vs. intermittent infusion. $J$ Clin Pharm Ther 2004;29:351-7. 
[25] Wysocki M, Delatour F, Faurisson F, Rauss A, Pean Y, Misset B, et al. Continuous versus intermittent infusion of vancomycin in severe staphylococcal infections: prospective multicenter randomized study. Antimicrob Agents Chemother 2001;45:2460-7.

[26] Healy DP, Polk RE, Garson ML, Rock DT, Comstock TJ. Comparison of steady-state pharmacokinetics of two dosage regimens of vancomycin in normal volunteers. Antimicrob Agents Chemother 1987;31:393-7. 
Fig. 1. Relationship between clearance of vancomycin $\left(C L_{v a n}\right)$ and $(A)$ measured creatinine clearance $\left(\mathrm{CL}_{\mathrm{Crea}}\right)$, (B) creatinine clearance estimated using the CockcroftGault formula $\left(\mathrm{CL}_{\mathrm{CG}}\right)$ and $(\mathrm{C})$ glomerular filtration rate estimated by the Hoek formula

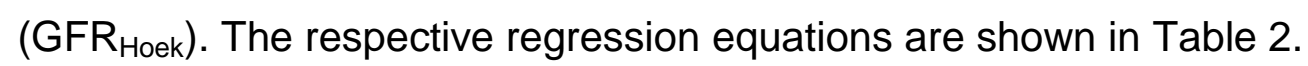


Table 1

Characteristics of the 25 patients (14 male, 11 female) in the study

\begin{tabular}{|c|c|c|}
\hline & Median & Range \\
\hline Age (years) & 59 & $31-82$ \\
\hline Total body weight (kg) & 80 & $45-120$ \\
\hline Body height (cm) & 173.5 & $160-187$ \\
\hline BMI $\left(\mathrm{kg} / \mathrm{m}^{2}\right)$ & 25.3 & $16.5-41.5$ \\
\hline \multicolumn{3}{|l|}{ APACHE II score } \\
\hline At admission & 22 & $8-36$ \\
\hline On study day & 19 & $5-29$ \\
\hline SOFA score on study day & 8 & $1-19$ \\
\hline $\mathrm{CL}_{\text {Crea }}(\mathrm{mL} / \mathrm{min})$ & 106 & $25-195$ \\
\hline \multirow[t]{2}{*}{ Daily dose on the study day (mg) } & 1500 & $432-3168$ \\
\hline & $n$ & $\%$ of total \\
\hline \multicolumn{3}{|l|}{ Focus of infection } \\
\hline Device-associated meningitis & 10 & 40 \\
\hline Peritonitis or abdominal infection & 8 & 32 \\
\hline Pneumonia & 4 & 16 \\
\hline Osteomyelitis & 2 & 8 \\
\hline Mediastinitis & 1 & 4 \\
\hline \multicolumn{3}{|l|}{ Concomitant therapy on study day } \\
\hline Meropenem & 15 & 60 \\
\hline Ceftazidime & 9 & 36 \\
\hline Rifampicin & 9 & 36 \\
\hline Ciprofloxacin & 7 & 28 \\
\hline Metronidazole & 6 & 24 \\
\hline Fluconazole & 4 & 16 \\
\hline Other antimicrobial agents & 15 & 60 \\
\hline Noradrenaline & 17 & 68 \\
\hline Furosemide & 10 & 40 \\
\hline Mechanical ventilation & 22 & 88 \\
\hline
\end{tabular}


BMI, body mass index; APACHE, Acute Physiology and Chronic Health Evaluation; SOFA, Sepsis-related Organ Failure Assessment; $\mathrm{CL}_{\text {Crea, }}$, measured creatinine clearance. 


\section{Table 2}

Regression equations of the dependence of vancomycin clearance ( $\left.C L_{v a n}\right)$ on measured creatinine clearance $\left(\mathrm{CL}_{\mathrm{Crea}}\right)$, creatinine clearance estimated using the Cockcroft-Gault formula ( $\mathrm{CL}_{\mathrm{CG}}$ ) and glomerular filtration rate estimated using the Hoek formula $\left(\right.$ GFR $\left._{\text {Hoek }}\right)$. Listed are point estimates (95\% confidence interval) of (a) slope and (b) $y$-intercept

\begin{tabular}{ccclc}
\hline & $\mathrm{a}$ & $\mathrm{b}(\mathrm{mL} / \mathrm{min})$ & $\begin{array}{l}\text { Coefficient of } \\
\text { determination }\left(r^{2}\right)\end{array}$ & $\begin{array}{l}P \text { - } \\
\text { value }\end{array}$ \\
\hline $\mathrm{CL}_{\text {Van }}=\mathrm{a} \times$ & $0.63(0.53-$ & $2.8(-8.0$ to & 0.88 & $<0.001$ \\
$\mathrm{CL}_{\text {Crea }}+\mathrm{b}$ & $0.73)$ & $13.6)$ & & 0.001 \\
$\mathrm{CL}_{\text {Van }}=\mathrm{a} \times \mathrm{CL}_{\mathrm{CG}}$ & $0.25(0.11-$ & $31.3(9.9-$ & 0.37 & \\
$+\mathrm{b}$ & $0.39)$ & $52.7)$ & & $<0.001$ \\
$\mathrm{CL}$ & $0.67(0.48-$ & $3.2(-15.5$ to & 0.70 & \\
$\mathrm{GFR}_{\text {Hoek }}+\mathrm{b}$ & $0.85)$ & $21.9)$ & & \\
\hline
\end{tabular}

